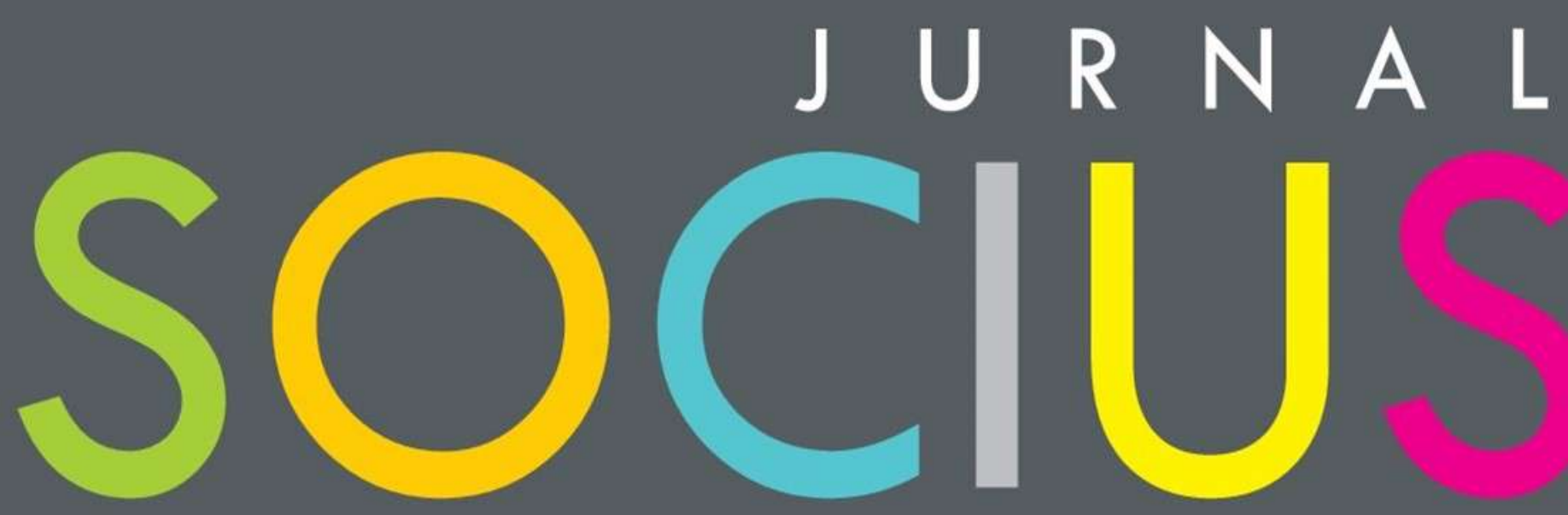

Journal of Sociology Research and Education

DITERBITKAN OLEH :

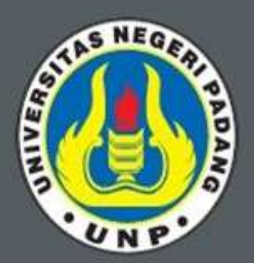

LABOR

JURUSAN SOSIOLOGI

FAKULTAS ILMU SOSIAL

UNIVERSITAS NEGERI PADANG

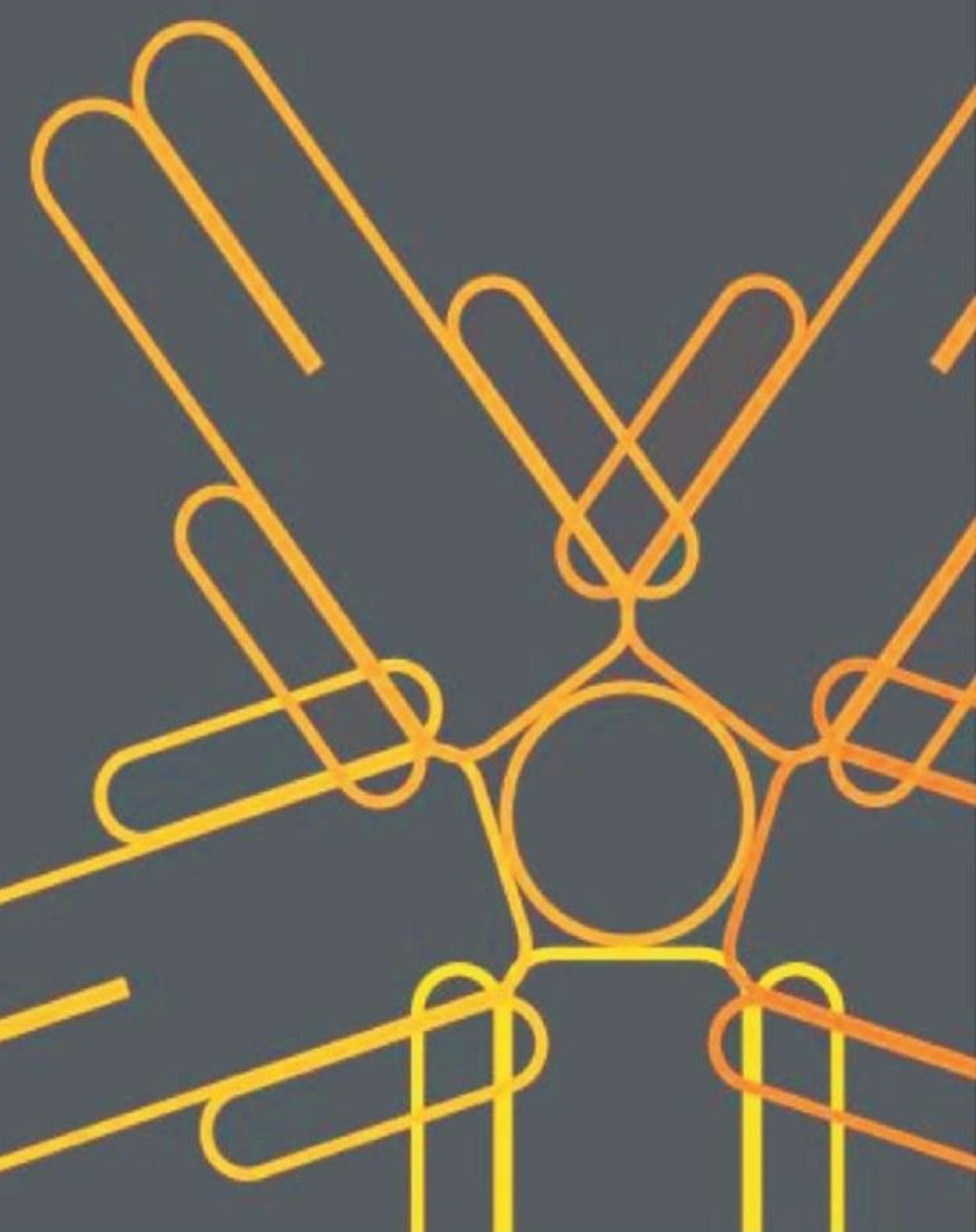




\section{SOCIUS}

Vol. 8, No. 1, Th. 2021

ISSN : 2356-4180 (cetak)

2442-8663 (online)

\begin{tabular}{|c|c|}
\hline $\begin{array}{c}\text { REDAKSI } \\
\text { JURNAL SOCIUS }\end{array}$ & DAFTAR ISI \\
\hline $\begin{array}{l}\text { Editor in Chief : } \\
\text { Desy Mardhiah } \\
\text { (Universitas Negeri Padang) }\end{array}$ & $\begin{array}{c}\text { Arni Darmayanti, Gede Budarsa } \\
\text { Peran Ganda Perempuan Bali di Masa Pandemi Covid-19 } \\
\text { Halaman 1-12 }\end{array}$ \\
\hline $\begin{array}{l}\text { Managing Editor : } \\
\text { Erda Fitriani } \\
\text { (Universitas Negeri Padang) }\end{array}$ & $\begin{array}{c}\text { Luthfi Hasanal Bolqiah, Riaty Raffiuddin } \\
\text { Dominasi Oligarki dalam Pembangunan Reklamasi Pantai Utara Jakarta } \\
\text { Halaman 13-25 }\end{array}$ \\
\hline $\begin{array}{l}\text { Editorial Board: } \\
\text { Elfitra Baikoeni } \\
\text { (Universitas Andalas) }\end{array}$ & $\begin{array}{c}\text { Rinel Fitlayeni, Ikhsan Muharma Putra, Marleni Marleni, } \\
\text { Elvawati Elvawati, Winda Sri Yulia Putri }\end{array}$ \\
\hline $\begin{array}{c}\text { Iskandar } \\
\text { (Universitas Trunojoyo) }\end{array}$ & $\begin{array}{c}\text { Penguatan Kapasitas Pedagang dalam Resolusi Konflik Asimetris di } \\
\text { Pasar Raya Padang Pasca Gempa }\end{array}$ \\
\hline $\begin{array}{c}\text { Ike Sylvia } \\
\text { (Universitas Negeri Padang) }\end{array}$ & Halaman 26-35 \\
\hline $\begin{array}{c}\text { Erianjoni } \\
\text { (Universitas Negeri Padang) } \\
\text { Emizal Amri } \\
\text { (Universitas Negeri Padang) }\end{array}$ & $\begin{array}{c}\text { Dahlia Morina Hutagalung, Ferdinand Kerebungu, Maryam } \\
\text { Lamadirisi } \\
\text { Perilaku Belajar Mahasiswa Batak Toba di Universitas Negeri Manado } \\
\text { Halaman 36-46 }\end{array}$ \\
\hline $\begin{array}{l}\text { Mohammad Isa Gautama } \\
\text { (Universitas Negeri Padang) }\end{array}$ & $\begin{array}{c}\text { Rifqi Asy'ari, Rusdin Tahir, Cecep Ucu Rakhman, Rifki } \\
\text { Rahmanda Putra }\end{array}$ \\
\hline $\begin{array}{l}\text { Khairul Fahmi } \\
\text { (Universitas Negeri Padang) }\end{array}$ & $\begin{array}{l}\text { Pengembangan Pariwisata Berbasis Masyarakat di Provinsi Jawa Barat } \\
\text { Halaman 47-58 }\end{array}$ \\
\hline $\begin{array}{c}\text { Reno Fernandes } \\
\text { (Universitas Negeri Padang) }\end{array}$ & $\begin{array}{c}\text { Reno Fernandes, Azwar Ananda, Maria Montessori, Firman } \\
\text { Firman, Eka Vidya Putra, Hendra Naldi, Erda Fitriani }\end{array}$ \\
\hline $\begin{array}{c}\text { Layout Editor: } \\
\text { Rhavy Ferdyan } \\
\text { Technical Support: } \\
\text { Rudi Mahesa }\end{array}$ & $\begin{array}{c}\text { Adaptasi Dosen Digital Immigrant Terhadap Pelaksanaan Pembelajaran } \\
\text { pada Masa Pandemi Covid-19 } \\
\text { Halaman 59-72 }\end{array}$ \\
\hline $\begin{array}{c}\text { Alamat Redaksi: } \\
\text { Jurusan Sosiologi FIS UNP } \\
\text { Jl. Prof.Dr.Hamka } \\
\text { Kampus UNP Air Tawar } \\
\text { e-mail: socius@ppj.unp.ac.id }\end{array}$ & \\
\hline $\begin{array}{l}\text { Penerbit } \\
\text { Labor Jurusan Sosiologi } \\
\text { Universitas Negeri Padang }\end{array}$ & \\
\hline
\end{tabular}




\title{
Pengembangan Pariwisata Berbasis Masyarakat di Provinsi Jawa Barat
}

Rifqi Asy'ari', Rusdin Tahir ${ }^{2}$, Cecep Ucu Rakhman ${ }^{3}$, Rifki Rahmanda Putra ${ }^{4}$

1,2,4 Universitas Padjadjaran

${ }^{3}$ Sekolah Tinggi Pariwisata Bandung

Email: rifqi19015@mail.unpad.ac.id

\begin{abstract}
Abstrak
Salah satu strategi pengembangan pariwisata di Provinsi Jawa Barat untuk mewujudkan pengembangan pariwisata berkelanjutan adalah berbasis masyarakat atau Community Based Tourism (CBT). Arikel ini bertujuan untuk melihat perkembangan pariwisata berbasis masyarakat yang terdapat di Provinsi Jawa Barat. Metode yang digunakan dalam penelitan ini adalah penelitian studi literatur dengan menggunakan alat pencarian berupa google scholar mengenai penelitianpenelitian tentang pengembangan pariwisata berbasis masyarakat di Provinsi Jawa Barat. Kriteria artikel yang dipilih yaitu memiliki fokus penelitian di Provinsi Jawa Barat, kemudian topik artikel yang dibahas adalah pariwisata berbasis masyarakat yang berisikan substansi tentang pelibatan masyarakat dalam pengembangan destinasi pariwisata Jawa Barat. Hasil penelitian menunjukkan bahwa keterlibatan masyarakat, peran pemangku kepentingan, dan pengurangan kemiskinan menjadi fokus utama pembahasan yang ada dalam pengembangan pariwisata berbasis masyarakat di Provinsi Jawa Barat. Provinsi tersebut memiliki potensi yang sangat besar untuk mengembangkan pariwisata berbasis masyarakat dengan mempertimbangkan aspek sinergitas antar sektor, pemerataan pembangunan dan pemberian manfaat kepada masyarakat dalam konteks pengembangan pariwisata.
\end{abstract}

\section{Kata kunci: CBT, Pariwisata Berbasis Masyarakat, Provinsi Jawa Barat, Pengembangan Pariwisata}

\begin{abstract}
This study aims to describe and analyze the learning behavior of Toba Batak students in higher education. This goal is based on the problem that there is a change in the learning behavior of Toba Batak students at Manado State University compared to when they were still in high school. The method used in this study is a qualitative research method. This method is used to determine the phenomenon of the learning behavior of One of the tourism development strategies in West Java Province to realize sustainable tourism development is community-based tourism (CBT). This article aims to see the development of community-based tourism in West Java Province. The method used in this research is a literature study using a search tool in the form of Google Scholar regarding research on community-based tourism development in West Java Province. The criteria for the selected article is to have a research focus in West Java Province, then the topic of the article discussed is community-based tourism which contains substance about community involvement in the development of West Java tourism destinations. The results of the study indicate that community involvement, the role of stakeholders, and poverty reduction are the main focus of discussion in the development of community-based tourism in West Java Province. The province has enormous potential to develop community-based tourism by considering aspects of synergy between sectors, equitable development, and providing benefits to the community in the context of tourism development.
\end{abstract}

Keyword: Community Based Tourism, CBT, Tourism Development, West Java Province

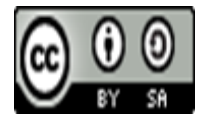




\section{Pendahuluan}

Fokus pengembangan pariwisata yang dilakukan Provinsi Jawa Barat untuk terwujudnya pengembangan pariwisata berkelanjutan, salah satunya adalah dengan pariwisata berbasis masyarakat atau yang biasa dikenal dengan Community Based Tourism (CBT). Hal itu dibuktikan melalui komitmen pemerintah daerah yang termaktub dalam Rencana Kerja Pemerintah Daerah (RKPD) Provinsi Jawa Barat tahun 2020, di mana salah satu agenda kerjanya adalah Gerakan Bangun Desa (Gerbang desa) dalam rangka membangun, memberdayakan masyarakat desa, dan meningkatkan pendapatan masyarakat di pedesaan. Salah satu bentuk dari gerakan tersebut adalah pengembangan desa wisata berbasis masyarakat (One Village, One Company). Namun demikian dalam Rencana Induk Pengembangan Pariwisata Provinsi Jawa Barat 2015-2025 terdapat beberapa isu strategis terkait masalah-masalah terkini mengenai CBT yaitu adalah lemahnya literasi dan kapasitas sumber daya manusia (SDM) mengenai pariwisata berbasis potensi lokal, pemerataan pembangunan, dan pemerataan pemberian manfaat pariwisata untuk masyarakat.

Definisi CBT itu sendiri adalah pariwisata yang menyadari kelangsungan budaya, sosial, dan lingkungan (Hadiwijoyo, 2012) dengan diinisiasi oleh masyarakat dan untuk masyarakat itu sendiri. Di mana menurut Rakhman (2019), dalam konsep CBT seyogyanya manfaat yang dirasakan bukan hanya bermanfaat bagi kelompok masyarakat tertentu saja, melainkan harus bermanfaat besar bagi mayoritas masyarakat di wilayah tersebut. Tujuan CBT itu sendiri untuk meminimalkan kerusakan lingkungan dan budaya, mengoptimalkan kepuasan pengunjung, dan memaksimalkan pertumbuhan ekonomi jangka panjang untuk wilayah tersebut (Strydom et al., 2019). Merujuk pada ASEAN Community Based Tourism Standard, CBT adalah kegiatan pariwisata yang dimiliki, dioperasikan, dikelola, dan dikoordinasikan oleh masyarakat; sehingga dapat berkontribusi pada kesejahteraan masyarakat dengan cara mendukung perikehidupan yang berkelanjutan dan melindungi tradisi sosial budaya yang bernilai serta sumber daya alam dan pusaka budaya. Secara umum, prinsip-prinsip yang melekat pada CBT adalah (1) mengenali, mendukung, dan mempromosikan kepemilikan pariwisata oleh masyarakat, (2) melibatkan anggota masyarakat sejak awal dalam berbagai aspek pengembangan, (3) mempromosikan kebanggaan masyarakat, (4) meningkatkan kualitas hidup masyarakat, (5) memastikan keberlanjutan lingkungan, (6) melestarikan keunikan karakter dan budaya lokal, (7) memfasilitasi proses belajar antar budaya, (8) menghormati perbedaaan budaya dan harga diri manusia, (9) mendistribusikan manfaat secara setara di antara anggota masyarakat dan (10) mengkontribusikan sebagian dari pendapatan untuk kegiatan pembangunan masyarakat.

Strategi perencanaan pembangunan kepariwisatan yang berbasis pada masyarakat memiliki tiga prinsip pokok diantaranya melibatkan masyarakat dalam pengambilan keputusan, terdapat kepastian masyarakat lokal menerima manfaat, dan pemberian edukasi tentang pariwisata kepada masyarakat lokal (Sunaryo, 2013: 140; Rizkianto et al., 2018). Pariwisata harus dikembangkan untuk memenuhi kebutuhan yang berimbang bagi kesejahteraan penduduk dan kebutuhan serta harapan para wisatawan. CBT juga merupakan sarana mengintegrasikan tujuan dari konsep umum pembangunan berkelanjutan karena memberikan kontrol lokal terhadap pembangunan, keterlibatan dalam perencanaan, membentuk aliran manfaat yang adil dan penggabungan nilai-nilai penduduk (Strydom et al., 2019). Karakteristiknya meliputi kontrol lokal terhadap pembangunan, keterlibatan masyarakat dalam perencanaan, aliran manfaat yang adil, dan penggabungan nilai-nilai penduduk (Koster, 2010: 4; Kline, 2017). Begitu pun pengembangan pariwisata di Provinsi Jawa Barat perlu memperhatikan pemberdayaan masyarakat dalam pengembangan kawasan wisata yang ada untuk mewujudkan pembangunan yang berkelanjutan.

Penelitian terdahulu menunjukkan betapa pentingnya studi CBT dalam pembangunan pariwisata daerah. Seperti yang telah dilakukan Nurvantina et al., (2018) dalam pengelolaan Kampung Wisata Kreatif Eco Bambu menyatakan mereka sudah melakukan upaya dalam 
pelaksanaan program CBT, meskipun program tersebut tidak melibatkan semua masyarakat Desa Ciumbuleuit. Kemudian penelitian terkait pengembangan kota yang memiliki sumber daya tambang yang terbatas menjadi kota wisata yang berbudaya dan memberikan dampak kehidupan sosial dan perekonomian masyarakat (Syafrini, Nurdin, Sugandi, \& Miko, 2018), model tata kelola pengembangan CBT, di mana pemerintah sebagai fasilitator dan regulator, swasta sebagai pengembang dan investor, dan masyarakat sebagai pelaksana atau subjek pembangunan (Husni \& Safaat, 2019). Bahkan di Jawa Barat secara khusus, sudah terdapat beberapa penelitian dengan konteks CBT dari sudut pandang ekonomi kerakyatan (Oktini, 2007); potensi daya tarik wisata pedesaan (Susyanti \& Latianingsih, 2013;Muftiadi, 2017; Andriani et al, 2018); pengembangan geowisata berbasis masyarakat (Darsiharjo, 2016); dan lain sebagainya. Adapun, studi diluar Jawa Barat yang menunjukkan pentingnya studi CBT terkait peran partisipasi masyarakat yang dipelopori kaum muda mulai dari proses perencanaan, pelaksanaan, pemanfaatan, dan evaluasi untuk pengembangan destinasi ekowisata Nagari Sungai Pinang (Fitriani et al, 2018).

Dari berbagai penelitian terdahulu tersebut, menunjukkan pentingnya CBT dalam kontribusi pengembangan pariwisata berkelanjutan terutama pada aspek peningkatan kesejahteraan ekonomi masyarakat (Muhammad, 2016). Jawa Barat yang memiliki program pembangunan Gerbang Desa dan One Village One Company seperti yang telah dijelaskan pada awal alinea, mengindikasikan bahwa komitmen pengembangan sektor pariwisata di provinsi tersebut dimulai dari desa sebagai ujung tombak, dengan memperhatikan aspek pro poor, pro job, pro growth, dan pro environment. Untuk meninjau sejauh mana penelitian yang terkait dalam penelitian dilakukan di Provinsi Jawa Barat, peneliti merasa perlu mengkaji studi literatur dengan mencoba menelaah literatur yang sudah ada atau yang telah dilakukan di Provinsi Jawa Barat terkait CBT. Maka dari itu, artikel ini berusaha mengkaji terkait sejauh mana pengembangan CBT yang terdapat di Provinsi Jawa Barat dan hal apa saja yang masih menjadi hambatan dalam pengembangan CBT di provinsi tersebut. Sehingga dapat terlihat keterbatasan penelitian CBT yang telah dilakukan, untuk kemudian dapat menjadi rekomendasi bagi penelitian selanjutnya. Kedepan, kajian-kajian mengenai CBT di Provinsi Jawa Barat diharapkan dapat memberikan gambaran dan dukungan dalam percepatan pembangunan pariwisata berbasis pemberdayaan masyarakat di provinsi tersebut.

\section{Metode Penelitian}

Penelitian ini merupakan penelitian studi literatur dengan menelaah artikel-artikel jurnal dengan kriteria penelitian yang akan ditentukan terlebih dahulu kriterianya. Penelitian studi literatur atau penelitian kepustakaan itu sendiri adalah penelitian yang dilakukan hanya berdasarkan atas karya tertulis, termasuk hasil penelitian baik yang telah dipublikasikan (Melfianora, 2017).

Penggunaan penelitian studi literatur juga telah banyak digunakan dalam penelitian terkait bidang pariwisata. Mulai dari penelitian konseptual mengenai mitigasi Covid-19 di desa wisata (Ferdiansyah et al., 2020); pengembangan pariwisata berbasis masyarakat dalam perspektif implementasi kebijakan (Febriandhika \& Kurniawan, 2020); evolusi mengenai istilah tipe wisatawan (Pitanatri, 2020); evolusi pengembangan wisata pedesaan (Ruiz-Real et al., 2020); mendefinisikan ulang konsep wisata pedesaan di Malaysia (Nair et al., 2014); dan lain sebagainya.

Dari beberapa penelitian yang menggunakan metode penelitian studi literatur, didapatkan bahwa tahapan dari penelitian studi literatur ini yaitu adalah 1) Menentukan kriteria atau parameter terkait artikel yang akan dikumpulkan sebagai database, 2) Menggabungkan berbagai penelitian yang didapat dan menyaringnya sesuai dengan kriteria yang telah ditentukan, dan 3) Menganalisis data-data tersebut. Maka untuk langkah yang pertama yaitu, kriteria data yang akan dianalisis merupakan data dari beberapa literatur tentang "pengembangan pariwisata berbasis masyarakat atau CBT" dengan lokasi kajian "Provinsi Jawa Barat" sebagai kata kunci, dapat diakses secara online pada alat pencarian google scholar, dan penelitian tersebut berada pada

Jurnal Socius: Journal of Sociology Research and Education Vol. 8, No. 1, Th. 2021 
rentan waktu satu sampai dua dekade ke belakang.

Kedua, peneliti melakukan pencarian dengan bantuan search engine seperti google scholar dengan cara memasukan kata kunci yang telah dijelaskan sebelumnya pada tahapan pertama dan membuat rentang khusus sejak tahun 2000 sampai dengan 2020. Maka peneliti pun mendapatkan 20 artikel yang terkait istilah pencarian tersebut dan dipilah kembali dengan mengelompokkan artikel yang terfokus pada istilah "Provinsi Jawa Barat" dan "pengembangan pariwisata berbasis masyarakat" agar lebih terfokus dengan menyesuaikannya dengan kriteria artikel yang telah ditetapkan sebelumnya.

Ketiga, didapat sepuluh (10) artikel (Tabel 1) dengan fokus penelitian yang masuk dalam kriteria untuk kemudian dilakukan pengkodean pada artikel-artikel tersebut dan dilakukan analisis isi. penelusuran pustaka tidak hanya untuk langkah awal menyiapkan kerangka penelitian, akan tetapi sekaligus memanfaatkan sumber-sumber perpustakaan untuk memperoleh data penelitian (Danandjaja, 2014).

Tabel 1. Database Literatur Terkait CBT di Jawa Barat

\begin{tabular}{|c|c|c|c|c|}
\hline Kode & Judul Penelitian & Peneliti & Tahun & Penerbit \\
\hline 1 & $\begin{array}{c}\text { Peran Perguruan Tinggi, Pemerintah } \\
\text { dan Investor dalam Membangun Wisata } \\
\text { Pedesaan Di Jawa Barat Sebagai Upaya } \\
\text { Mengurangi Kemiskinan } \\
\end{array}$ & Oktini & 2007 & $\begin{array}{c}\text { MIMBAR, Jurnal } \\
\text { Sosial\&Pembangunan }\end{array}$ \\
\hline 2 & $\begin{array}{l}\text { Potensi Desa melalui Pariwisata } \\
\text { Pedesaan }\end{array}$ & $\begin{array}{c}\text { Susyanti \& } \\
\text { Latianingsih }\end{array}$ & 2013 & $\begin{array}{l}\text { Jurnal Ekonomi dan } \\
\text { Bisnis }\end{array}$ \\
\hline 3 & $\begin{array}{c}\text { Pengembangan Geopark Ciletuh } \\
\text { Berbasis Partisipasi Masyarakat } \\
\text { Sebagai Kawasan Geowisata di } \\
\text { Kabupaten Sukabumi }\end{array}$ & Darsiharjo & 2016 & $\begin{array}{l}\text { Jurnal Manajemen } \\
\text { Resort dan Leisure }\end{array}$ \\
\hline 4 & $\begin{array}{c}\text { Pengembangan Desa Wisata Dan } \\
\text { Potensinya di Kabupaten Pangandaran }\end{array}$ & Muftiadi & 2017 & $\begin{array}{l}\text { Faculty of Social and } \\
\text { Political Sciences } \\
\text { Universitas Padjadjaran }\end{array}$ \\
\hline 5 & $\begin{array}{c}\text { Analisis Persepsi Pengelola dan } \\
\text { Masyarakat Mengenai Program } \\
\text { Community Based Tourism di Kampung } \\
\text { Wisata Kreatif Eco Bambu Cipaku }\end{array}$ & $\begin{array}{l}\text { Nurvantina } \\
\text { et al., }\end{array}$ & 2018 & $\begin{array}{l}\text { Journal of Indonesian } \\
\text { Tourism, Hospitality } \\
\text { and Recreation }\end{array}$ \\
\hline 6 & $\begin{array}{c}\text { Potensi Pengembangan Agrowisata } \\
\text { Berbasis Komunitas Kabupaten } \\
\text { Bandung Barat }\end{array}$ & $\begin{array}{l}\text { Andriani et } \\
\text { al., }\end{array}$ & 2018 & $\begin{array}{l}\text { Jurnal Ilmu Pertanian } \\
\text { dan Pertenakan }\end{array}$ \\
\hline 7 & $\begin{array}{l}\text { The Concept of Developing Local } \\
\text { Wisdom-based Tourism Villages in } \\
\text { Cirebon Regency, West Java, } \\
\text { Indonesia: Integrated Marketing } \\
\text { Communication Perspective }\end{array}$ & $\begin{array}{l}\text { Chamidah, } \\
\text { et al }\end{array}$ & 2018 & $\begin{array}{l}\text { 2nd International } \\
\text { Conference on Social } \\
\text { and Political } \\
\text { Development } \\
\text { (ICOSOP) }\end{array}$ \\
\hline 8 & $\begin{array}{c}\text { Pesona Kearifan Lokal Sebagai Wahana } \\
\text { Peningkatan Produktifitas Ekonomi } \\
\text { Masyarakat }\end{array}$ & Muhammad & 2018 & $\begin{array}{l}\text { Jurnal Pemberdayaan } \\
\text { Masyarakat: Media } \\
\text { Pemikiran dan Dakwah } \\
\text { Pembangunan } \\
\end{array}$ \\
\hline 9 & $\begin{array}{c}\text { Pengembangan Program Pelibatan } \\
\text { Masyarakat di Wana Wisata Kawah } \\
\text { Putih } \\
\end{array}$ & $\begin{array}{l}\text { Soepom et } \\
\text { al }\end{array}$ & 2018 & $\begin{array}{l}\text { Journal of Indonesian } \\
\text { Tourism, Hospitality } \\
\text { and Recreation } \\
\end{array}$ \\
\hline 10 & $\begin{array}{l}\text { Pemberdayaan Masyarakat di Desa } \\
\text { Wisata Cibuntu Kabupaten Kuningan } \\
\text { Provinsi Jawa Barat }\end{array}$ & $\begin{array}{l}\text { Kartika et } \\
\quad \text { al., }\end{array}$ & 2019 & $\begin{array}{l}\text { Journal of Indonesian } \\
\text { Tourism, Hospitality } \\
\text { and Recreation }\end{array}$ \\
\hline
\end{tabular}

Sumber: Hasil Analisis Data Peneliti (2020)

Jurnal Socius: Journal of Sociology Research and Education Vol. 8, No. 1, Th. 2021 


\section{Hasil dan Pembahasan}

\section{Konsep Pengembangan CBT di Jawa Barat}

"Pengembangan CBT menjadi fokus pemerintah untuk mengatasi kemiskinan dan meningkatkan kesejahteraan di desa-desa yang tersebar di Provinsi Jawa Barat". Begitulah yang tersirat dari kesepuluh artikel yang dianalisis (Tabel 2). Analisis data yang ada dengan pemberian kode artikel berdasarkan susunan nomor artikel pada Tabel 2, menentukan hasil dan pembahasan untuk memberikan gambaran pada penulisan penelitian ini. Hasil analisis penelitian ini akan memperlihatkan kecenderungan metode yang digunakan, kecenderungan isu-isu yang dibahas, lokasi penelitian, dan lain sebagainya. Sehingga dengan demikian, akan terlihat dengan jelas isu, lokasi, dan lain sebagainya yang belum dibahas pada penelitian mengenai pengembangan CBT di Jawa Barat dengan metode yang tepat.

\section{Tabel 2. Analisis Penelitian Terdahulu Terkait CBT di Jawa Barat}

\begin{tabular}{|c|c|c|c|c|}
\hline Kode & Penulis & Lokasi & Metode & Subtansi Pembahasan (Isu Strategis) \\
\hline 1 & Oktini (2007) & Jawa Barat & Kualitatif & $\begin{array}{c}\text { “.....peran Perguruan Tinggi, Pemerintah } \\
\text { dan Investor dalam membangun wisata } \\
\text { pedesaan di Jawa Barat sebagai upaya } \\
\text { mengurangi kemiskinan” }\end{array}$ \\
\hline 2 & $\begin{array}{l}\text { Susyanti \& } \\
\text { Latianingsih } \\
\text { (2013) }\end{array}$ & Jawa Barat & Kualitatif & $\begin{array}{c}\text { "........mengidentifikasi dan mengenali } \\
\text { potensi suatu desa untuk menjadi desa } \\
\text { wisata" }\end{array}$ \\
\hline 3 & $\begin{array}{l}\text { Darsiharjo } \\
\text { (2016) }\end{array}$ & $\begin{array}{l}\text { Kabupaten } \\
\text { Sukabumi, } \\
\text { Jawa Barat }\end{array}$ & Kualitatif & $\begin{array}{c}\text { “....pengembangan geopark ciletuh } \\
\text { berbasis partisipasi masyarakat sebagai } \\
\text { kawasan geowisata di Kabupaten } \\
\text { Sukabumi, Jawa Barat" }\end{array}$ \\
\hline 4 & Muftiadi (2017) & $\begin{array}{l}\text { Kabupaten } \\
\text { Pangandaran, } \\
\text { Jawa Barat }\end{array}$ & Kualitatif & $\begin{array}{c}\text { ".......membangun konsep desa wisata di } \\
\text { Kawasan Pangandaran yang komprehensif } \\
\text { berbasis masyarakat..." }\end{array}$ \\
\hline 5 & $\begin{array}{l}\text { Nurvantina et } \\
\text { al., (2018) }\end{array}$ & $\begin{array}{l}\text { Kampung } \\
\text { Wisata Kreatif } \\
\text { Eco Bambu, } \\
\text { Jawa Barat }\end{array}$ & Kuantitatif & $\begin{array}{c}\text { “.....mengetahui persepsi pengelola dan } \\
\text { masyarakat mengenai program Community } \\
\text { Based Tourism dan menganalisis } \\
\text { perbandingan persepsi..." }\end{array}$ \\
\hline 6 & $\begin{array}{l}\text { Andriani et al., } \\
\text { (2018) }\end{array}$ & $\begin{array}{l}\text { Desa Cibodas, } \\
\text { Jawa Barat }\end{array}$ & Kualitatif & $\begin{array}{c}\text { “...perumusan langkah-langkah kebijakan } \\
\text { yang kongkrit dan operasional guna } \\
\text { tercapainya pengelolaan objek agrowisata } \\
\text { sebagai salah satu sumber pendapatan } \\
\text { masyarakat...." }\end{array}$ \\
\hline 7 & $\begin{array}{l}\text { Chamidah, et al } \\
\text { (2018) }\end{array}$ & $\begin{array}{l}\text { Cirebon, Jawa } \\
\text { Barat }\end{array}$ & Kualitatif & $\begin{array}{c}\text { “.....langkah implementasi, desa wisata } \\
\text { memutuskan asimilasi program komunikasi, } \\
\text { memilih media, membuat pesan, dan } \\
\text { menentukan momen" }\end{array}$ \\
\hline 8 & $\begin{array}{l}\text { Muhammad } \\
\text { (2018) }\end{array}$ & $\begin{array}{l}\text { Pantai } \\
\text { Pangandaran, } \\
\text { Jawa Barat }\end{array}$ & Kualitatif & $\begin{array}{c}\text { "proses pelibatan masyarakat yang panjang } \\
\text { sehingga menghasilkan bentuk pengelolaan } \\
\text { CBT...." }\end{array}$ \\
\hline 9 & $\begin{array}{l}\text { Soepom et al } \\
\quad(2018)\end{array}$ & $\begin{array}{l}\text { Wana Wisata } \\
\text { Kawah Putih, } \\
\text { Jawa Barat }\end{array}$ & Kuantitatif & $\begin{array}{c}\text { "....identifikasi program pelibatan } \\
\text { masyarakat..." }\end{array}$ \\
\hline 10 & $\begin{array}{l}\text { Kartika et al., } \\
\text { (2019) }\end{array}$ & $\begin{array}{l}\text { Desa Cibuntu, } \\
\text { Jawa Barat }\end{array}$ & Kualitatif & $\begin{array}{c}\text { "....mengoptimalkan pemberdayaan } \\
\text { masyarakat..." }\end{array}$ \\
\hline
\end{tabular}

Sumber: Hasil Analisis Data Peneliti (2020) 
Dari kesepuluh artikel yang dianalisis di atas (Tabel 2), artikel-artikel tersebut dapat dikelompokkan menjadi 5 kelompok yaitu artikel 1 dan 5 membahas tentang stakeholder dalam pengembangan CBT (Oktini, 2007; dan Nurvantina et al., 2018), artikel 2, 4, dan 10 membahas tentang pengembangan desa wisata berbasis masyarakat (Susyanti \& Latianingsih, 2013; Muftiadi, 2017; dan Kartika et al., 2019), artikel 3 dan 6 membahas tentang tipe pengembangan destinasi wisata yang mengadopsi paradigma CBT seperti geopark dan agrowisata (Darsiharjo, 2016; dan Andriani et al., 2018), artikel 7 yang membahas CBT dari perspektif komunikasi pariwisata, dan artikel 8 dan 9 yang terfokus kepada perlibatan masyarakat sebagai cara meningkatkan kesejahteraan sosial ekonomi (Muhammad, 2018; dan Soepom et al., 2018). Adapun hasil penelitian yang terdapat dalam artikel yang dianalisis terkait pengembangan CBT di Jawa Barat diantaranya:

Pada artikel 1 dijelaskan bahwa masih terjadi tumpang tindih peran yang terjadi dalam pembangunan CBT di Jawa Barat (Oktini, 2007). Pada artikel 2 dijelaskan bahwa perlu pemberian pelatihan dalam pengelolaan satu kawasan untuk menunjang pelibatan masyarakat (Susyanti \& Latianingsih, 2013). Hal tersebut selaras dengan apa yang dikatakan pada artikel 3, di mana ketersediaan zona untuk pengembangan untuk menunjang ekonomi masyarakat (wilayah pemanfaatan masyarakat) secara langsung dapat menjadikan masyarakat lokal sebagai aktor kunci pada setiap tahap pelaksanaan dan pengelolaan (Darsiharjo, 2016). Dibahas lebih lanjut pada artikel 4, bahwa perlu digaris bawahi, untuk meningkatkan kegiatan ekonomi atau pendapatan masyarakat, yang dikembangkan di suatu destinasi harus memiliki daya tarik wisata yang spesifik (misalnya goa, sungai, danau, perkebunan dan alam perdesaan yang khas, pantai dan lain sebagainya) dan pengembangan kapasitas masyarakat, harus selaras dengan aktivitas wisata yang sudah ada sebagai bentuk keterhubungan akses terhadap sumber daya pariwisata di kawasan tersebut (Muftiadi, 2017). Maka dari itu pada artikel 10 disebutkan bahwa bantuan pihak luar seperti pendampingan dari para akademisi maupun praktisi mutlak diperlukan guna mengoptimalkan potensi yang dimiliki oleh masyarakat sesuai dengan sumber daya yang ada pada daerah mereka (Kartika et al., 2019).

Untuk metode penelitian yang digunakan dari kesepuluh artikel di atas (Tabel 2), dapat dikelompokkan ke dalam dua penggunaan metode yaitu 2 artikel (Nurvantina et al., 2018 dan Soepom et al., 2018) menggunakan metode kuantitatif dan 8 artikel (Oktini, 2007; Susyanti \& Latianingsih, 2013; Muftiadi, 2017; Kartika et al., 2019; Darsiharjo, 2016; Andriani et al., 2018; dan Muhammad, 2018) menggunakan metode kualitatif. Sehingga dapat dikatakan bahwa mayoritas penelitian terkait CBT di Jawa Barat menggunakan metode kualitatif. Metode kualitatif yang dilakukan rata-rata menggunakan pedekatan secara langsung turun kelapangan (observasi) dan mewawancarai masyarakat yang ada.

Pada artikel 5 dan 6, permasalahan lain terkait CBT di Jawa Barat yaitu terdapat perbedaan persepsi pengelola dan masyarakat mengenai program CBT (Nurvantina et al., 2018), peningkatan kesadaran masyarakat akan pentingnya pengembangan pariwisata berbasis komunitas (Andriani et al., 2018). Pada artikel 7 disebutkan bahwa CBT yang merupakan proses dari bawah ke atas dalam konteks pengembangan pariwisata, membutuhkan bimbingan pemangku kepentingan, terutama dalam pemberdayaan sumber daya manusia untuk mengelola pariwisata desa dan pembuatan kebijakan untuk mengembangkannya (Chamidah et al., 2018). Benefitnya adalah seperti yang disebutkan pada artikel 8 yaitu pengelolaan destinasi pariwisata akan minim konflik, karena CBT mendorong masyarakat untuk memiliki rasa memiliki yang tinggi terhadap sumber daya yang mereka kelola (Muhammad, 2018).

Pada dasarnya di Jawa Barat sendiri masih terdapat temuan lain yang menunjukkan permasalahan lain, seperti hasil penelitian artikel 9 yaitu terdapat perbedaan persepsi antara pengelola dan masyarakat pada indikator yang meliputi (1) Mengakui mendukung dan mengembangkan kepemilikan komunitas dalam industri pariwisata, (2) Mengikutsertakan anggota komunitas dalam memulai setiap aspek, (3) Mengembangkan kebanggaan komunitas,

Jurnal Socius: Journal of Sociology Research and Education Vol. 8, No. 1, Th. 2021 
(4) Mengembangkan kualitas hidup komunitas, (5) Program pelibatan masyarakat dalam pengelolaan Wana Wisata Kawah Putih yang tepat untuk dilaksanakan (Soepom et al., 2018). Di mana hasil dari sudut pandang pengelola sudah mengakui bahwa perlibatan masyarakat dalam industri pariwisata dari kelima indikator tersebut sudah maksimal, sedangkan masyarakat masih memiliki persepsi yang negatif atau berbanding terbalik dengan pernyataan pengelola.

\section{Masyarakat Fokus Utama CBT}

Fokus utama yang dibahas dari kesepuluh artikel yang dianalisis di atas, dapat disimpulkan bahwa yang menjadi isu strategis atau topik pembahasan yang ada dalam pengembangan CBT di Jawa Barat yaitu (1) Masyarakat menjadi fokus utama, (2) Peran stakeholder atau pemangku kepentingan, dan (3) Pengurangan kemiskinan. Pertama, pengembangan CBT menjadikan masyarakat sebagai fokus utama dalam pengembangan karena partisipasi masyarakat secara langsung mau pun tidak langsung dalam suatu kawasan berperan sangat besar dalam pariwisata. Seperti halnya yang dibahas dalam artikel 2 yang ditulis oleh Susyanti \& Latianingsih, (2013) yang mengatakan kecenderungan wisatawan sekarang ini lebih rasional dan memiliki karakter bahwa kepuasan wisatawan tidak hanya didasarkan pada fasilitas modern, pariwisata akan tetap pada keleluasaan dan intensitas interaksi dengan lingkungan dan masyarakat lokal. Maka dari hasil penelitian tersebut untuk menyiapkan penduduk agar mampu mengelola desa wisata perlu diberikan pelatihan kompetensi untuk mengelola desa wisata, sehingga pelestarian budaya dan pengentasan kemiskinan dapat terwujud. Temuan yang terdapat dalam penelitian tersebut sekiranya perlu diantisipasi dalam pengembangan CBT seperti pembentukan kurikulum pelatihan yang sesuai dengan kompetensi yang dapat dimiliki desa wisata yang pada dasar masyarakat desa belum memiliki pengetahuan dan keterampilan yang memadai dalam mengelola desa wisata.

Berdasarkan teori yang dikemukakan Strydom et al., (2019), keterlibatan masyarakat dalam pengembangan CBT memberi mereka kekuatan untuk membuat keputusan tentang masalah yang melibatkan aset mereka termasuk sumber daya komunal, standar kehidupan, dan masa depan mereka. Menurut pendapat yang dibahas pada artikel 8 yang ditulis Muhammad (2016), penerapan konsep partisipasi masyarakat dengan CBT merupakan hal yang sangat luar biasa hasilnya karena yang pertama keinginan pembangunan berawal dari masyarakat, kedua tidak akan pernah ada komplain dari masyarakat, dan ketiga yaitu terciptanya rasa memiliki yang tinggi. Keberhasilan pemberdayaan masyarakat melalui pengembangan desa wisata dapat meningkatkan kepercayaan diri dan jati diri masyarakat di suatu kawasan itu sendiri.

Kedua, terkait peran stakeholder atau pemangku kepentingan, merupakan dasar dari keberhasilan CBT. Keberhasilan pengembangan CBT diindikasikan dengan berjalannya sinergitas antara setiap sektor dalam pengembangan kawasan pariwisata yang ada. Peran stakeholder atau pemangku kepentingan baik di pusat maupun daerah sangat berperan penting. Namun, masih ada permasalahan yang terjadi di Jawa Barat, contohnya yaitu pada kerjasama antar masyarakat dan pemerintah daerah sebagai pemangku kebijakan dari wilayah administratif Geopark Ciletuh terlihat bergerak kurang cepat dalam hal pengembangan kawasan yang terlihat dari belum adanya payung hukum yang dikeluarkan oleh pihak pemerintah daerah dan belum adanya perkembangan yang terlihat signifikan di kawasan Geopark Ciletuh (Darsiharjo, 2016). Maka dari itu, integrasi antar stakeholder yang dipayungi hukum dari pembuat kebijakan perlu diciptakan secara bertahap di kawasan Geopark Ciletuh dengan mempertimbangkan aspek ekonomi, sosial, budaya, lingkungan dan politik.

Berdasarkan teori yang diungkapkan Hendrawan (2016), konektifitas dan sinergitas stakeholder atau pemangku kepentingan perlu berjalan dalam pengembangan, perencanaan dan pengelolaan pariwisata untuk menunjang keberlanjutan dari satu kawasan pariwisata yang dibangun. Namun perlu digarisbawahi, bahwa tata kelola CBT adalah bentuk pengelolaan pariwisata yang menjadikan masyarakat sebagai pelaku utama mulai dari tahap perencanaan pariwisata. Di mana masyarakat berperan penuh sebagai perencana, investor, pelaksana,

Jurnal Socius: Journal of Sociology Research and Education Vol. 8, No. 1, Th. 2021 
pengelola, pemantau maupun evaluator (Muhammad, 2018). Maka, partisipasi masyarakat dalam perencanaan, pengembangan dan pengelolaan perlu menjadi kunci dalam menjalankan prinsip CBT di Provinsi Jawa Barat.

Ketiga, dalam konteks pengurangan kemiskinan, pada hakekatnya CBT adalah cara untuk memastikan bahwa industri pariwisata memberi manfaat bagi penduduk setempat, meningkatkan standar hidup dan kualitas hidup. Pariwisata harus dikembangkan untuk memenuhi kebutuhan yang sama baiknya bagi kesejahteraan penduduk dan kebutuhan serta harapan para wisatawan. Destinasi yang dikembangkan melalui konsep CBT nantinya akan menjadi pusat informasi inkubator ekonomi lokal yang merupakan nilai tambah bagi pengembangan CBT. CBT dianggap sebagai alat yang mengintegrasikan tujuan dari konsep umum pembangunan berkelanjutan dan didasarkan pada inklusi masyarakat lokal dalam pengembangan industri pariwisata.

Faktanya, karakteristiknya meliputi kontrol lokal terhadap pembangunan, keterlibatan masyarakat dalam perencanaan, aliran distribusi manfaat yang adil, dan penggabungan nilainilai penduduk (Koster, 2010: 4). Oleh karena itu, CBT adalah cara untuk memastikan bahwa industri pariwisata memberi manfaat bagi penduduk setempat, meningkatkan standar hidup dan kualitas hidup. Pariwisata harus dikembangkan untuk memenuhi kebutuhan yang sama baiknya bagi kesejahteraan penduduk dan kebutuhan serta harapan para wisatawan. CBT dianggap sebagai alat yang mengintegrasikan tujuan dari konsep umum pembangunan berkelanjutan. CBT harus memenuhi kriteria yang membuatnya masuk akal secara ekonomi serta sosial, budaya dan ekologis yang kompatibel dengan masyarakat di mana semua berlangsung. Ini berarti bahwa inisiatif CBT harus layak secara komersial dan dioperasikan sebagai entitas komersial. Ada skeptisisme yang berkembang tentang nilai CBT dalam memberikan pengurangan kemiskinan karena ketidakmampuan sebagian besar skema untuk mencapai tujuan mereka yang paling mendasar yaitu mengarahkan aliran manfaat yang berkelanjutan dan bermakna bagi masyarakat miskin.

Pada akhirnya dapat dikatakan bahwa pengembangan CBT di Provinsi Jawa Barat dari beberapa penelitian yang telah ditinjau atau review, menunjukkan bahwa komitmen perangkat daerah dalam mengembangkan pariwisata yang pro poor, misalnya pada program-program pengembangan desa wisata sangatlah penting. Semangat dan partisipasi masyarakat menjadi kunci dalam pembangunan pariwisata di Provinsi Jawa Barat. Perlibatan masyarakat mulai dari tahap perencanaan hingga evaluasi menjadikan masyarakat tersebut semakin berkarakter, karena memupuk rasa kebanggaan mereka terhadap daerahnya dan semakin mempertahankan jati diri mereka.

\section{Rekomendasi Penelitian CBT ke Depan}

Terdapat sepuluh (10) prinsip dasar mengenai CBT yang dikeluarkan oleh The United Nations Environment Program (UNEP) dan World Tourism Organization (WTO) pada tahun 2005 yang didalamnya mengedepankan kesejahteraan masyarakat dan tercatat dalam Nurvantina et al., (2018), diantaranya: (1) Mengakui, mendukung dan mengembangkan kepemilikan komunitas dalam industri pariwisata, (2) Mengikutsertakan anggota komunitas dalam memulai setiap aspek, (3) Mengembangkan kebanggaan komunitas, (4) Mengembangkan kualitas hidup komunitas, (5) Menjamin keberlanjutan lingkungan, (6) Mempertahankan keunikan, karakter dan budaya di area lokal, (7) Membantu berkembangnya pembelajaran tentang pertukaran budaya pada komunitas, (8) Menghargai perbedaan budaya dan martabat manusia, (9) Mendistribusikan keuntungan secara adil kepada anggota komunitas, (10) Berperan dalam menentukan persentase pendapatan (pendistribusian pendapatan) dalam proyek-proyek yang ada di komunitas. Namun demikian, hasil analisis dari kesepuluh artikel yang direview pada penelitian ini (Tabel 2) baru berkaitan kepada beberapa prinsip CBT.

Dari 10 prinsip CBT di atas, di antaranya yang telah dilakukan penelitian di Provinsi Jawa Barat adalah prinsip CBT yang ke 7 terkait keterlibatan stakeholder dalam pengelolaan destinasi

Jurnal Socius: Journal of Sociology Research and Education Vol. 8, No. 1, Th. 2021 
wisata berbasis masyarakat (Oktini 2007; dan Nurvantina et al., 2018) untuk menunjang berkembangnya literasi pada masyarakat. Selanjutnya prinsip CBT yang ke 3, 6 dan 8 terkait pengembangan CBT berbasis lokalitas, dalam hal ini adalah desa wisata (Susyanti \& Latianingsih, 2013; Muftiadi, 2017; dan Kartika et al., 2019); pengembangan konsep pariwisata berkelanjutan seperti geopark (Darsiharjo, 2016); dan agrowisata (Andriani et al., 2018) untuk mengangkat identitas masyarakat, mempertahankan daerahnya, dan menjadi pusat pembelajaran budaya.

Prinsip CBT ke 1 yang telah diteliti di Jawa Barat yaitu adalah penelitian terkait pengembangan kearifan lokal di Cirebon dalam perspektif komunikasi pemasaran (Chamidah et al., 2018) dengan tujuan pengakuan dan pengembangan aset masyarakat dalam industri pariwisata. Terakhir yaitu prinsip CBT ke 2, 4 dan 9 terkait penelitian perlibatan masyarakat (Soepom et al., 2018) dan peningkatan ekonomi masyarakat (Muhammad, 2018). Dari hasil artikel yang dianalisis, kesepuluh artikel yang ada juga cenderung memfokuskan penelitian pada bentuk evaluasi pelaksanaan CBT, atau tidak spesifik pada model pengembangan CBT di Provinsi Jawa Barat. Sebagai contoh dapat dilihat pada artikel 5 dan artikel 6 yang mengevaluasi tentang prinsip atau pelibatan masyarakat dalam CBT hanya meninjau bahwa potensi komoditas pariwisata yang beragam, jumlah wisatawan yang meningkat setiap tahunnya, dan peningkatan kesadaran masyarakat akan pentingnya pengembangan pariwisata merupakan faktor utama dalam pengembangan agrowisata berbasis masyarakat di Desa Cibodas. Pada akhirnya keseluruhan artikel yang dianalisis mayoritas menyebutkan perlu diciptakan sinergitas antar pihak juga harus bersama saling mengerti kendala dan kesulitan satu sama lain. Hal yang terpenting adalah menjalin komunikasi yang baik sehingga terhindar dari kesalahpahaman. Sinergitas dalam pengembangan perlu ada atau dibangun untuk menciptakan CBT. Maka partisipasi masyarakat untuk menghubungkan antar sektor menjadi pekerjaan rumah untuk dijalankan.

Berdasarkan teori (Oktini, 2007), bila masyarakat desa, perguruan tinggi, pemerintah dan investor dapat bekerjasama dengan baik maka akan terjadi suatu sinergi sehingga diharapkan kemiskinan dapat ditanggulangi. Keberadaan desa wisata juga akan berperan bagi pemerataan pendapatan. Kegiatan pariwisata ini dapat menjadi dual-income bagi warga masyarakat (Muftiadi, 2017). Dari analisis artikel yang ada, pengembangan CBT dapat mengurangi kemiskinan di suatu daerah sebab dengan pengembangan tersebut membuka banyak peluang tambahan kerja bagi masyarakat tanpa harus meninggalkan kebiasaan atau rutinitas yang ada yang menjadi dampak secara langsung bagi masyarakat. CBT dapat diaplikasikan melalui usaha mikro yang dapat dikembangkan yaitu (1) Akomodasi pondok wisata (home stay) dengan tetap memperhatikan keunikan lokal; (2) Usaha makanan dan minuman dengan menonjolkan alat, penyajian, menu dan bahan setempat dengan pengolahan higienis; dan (3) Usaha atraksi pariwisata, olahraga air, menangkap ikan, kegiatan di sawah, di hutan, membuat cindera mata dengan melibatkan wisatawan (Oktini, 2007).

CBT diartikan sebagai model pengembangan pariwisata yang berasumsi bahwa pariwisata harus berangkat dari kesadaran nilai-nilai kebutuhan, inisiatif dan peluang masyarakat lokal, CBT bukanlah bisnis pariwisata yang bertujuan hanya untuk memaksimalkan profit atau keuntungan bagi para investor namun CBT lebih terkait dengan dampak pariwisata bagi masyarakat setempat dan sumber daya lingkungan (Chamidah et al., 2018). Satu aspek pembangunan yang penting adalah pengembangan dalam bidang ekonomi, di mana kepariwisataan termasuk salah satu sektor pembangunan yang diharapkan dapat menunjang laju pemerataan di bidang pengembangan ekonomi Indonesia, melalui berbagai aspek yang terkandung di dalamnya seperti penerimaan devisa, pemerataan pendapatan ekonomi rakyat, memperluas kesempatan kerja dan bahkan pariwisata saat ini dibebani pula satu pendekatan ekonomi dengan turut serta mengentaskan kemiskinan (pro poor tourism) (UU RI No 10 Tahun 2009). Pelibatan masyarakat secara langsung menjadi sarana untuk pengurangan kemiskinan

Jurnal Socius: Journal of Sociology Research and Education Vol. 8, No. 1, Th. 2021 
dalam pengembangan pariwisata sesuai dengan nilai-nilai yang terkandung dalam CBT.

Meskipun demikian, masih banyak gap yang menjadi perbincangan dalam berbagai literatur CBT di Provinsi Jawa Barat. Antara lain (1) Pola tata kelola destinasi yang dinilai masyarakat belum sepenuhnya melibatkan mereka (Rahmafitria \& Rahmafitria, 2018); (2) Sinergi antar stakeholder/pemangku kepentingan di destinasi terutama pemerintah dengan masyarakat yang belum optimal (Darsiharjo, 2016); (3) Partisipasi masyarakat dalam tiap proses perencanaan, manajemen, hingga evaluasi; dan (4) CBT dalam perspektif keberlanjutan lingkungan fisik destinasi masih menjadi hal yang belum banyak diteliti dan perlu dicari solusi jalan keluarnya di Provinsi Jawa Barat.

Terkait dengan pengembangan CBT dalam perspektif menjaga keberlanjutan lingkungan, hal itu selaras dengan salah satu prinsip CBT dan juga dengan apa yang dikemukakan oleh Muhammad (2016), bahwa keberlanjutan lingkungan suatu destinasi perlu dijaga keberlanjutannya oleh masyarakat setempat dengan memperhatikan (1) Perhatian khusus terhadap perubahan iklim, sehingga prosesnya dapat dilaksanakan melalui pendidikan dan peningkatan kesadaran di masyarakat, industrialis di bidang pariwisata dan konservasi energi dan air dapat diterapkan pada penggunaan teknologi terbarukan; (2) Industri pengolahan dengan produk ramah lingkungan dan meningkatkan kapasitas pengrajin masih perlu ditingkatkan; dan (3) Budaya dan tradisi dalam pelestarian melalui modifikasi terbatas pada pemanfaatan sumber daya lokal. Pada akhirnya, penelitian ilmiah perlu dilakukan oleh peneliti selanjutnya, tentang bagaimana pengembangan tata kelola destinasi pariwisata Provinsi Jawa Barat yang terintegrasi antar stakeholder atau pemangku kepentingan dan penelitian partisipatif terkait perlibatan masyarakat sebagai pemeran kunci dalam perencanaan, pengelolaan, dan evaluasi di destinasi pariwisata, tanpa terlepas dari prinsip-prinsip keberlanjutan lingkungan. Menimbang pada umumnya penelitian terkait pengembangan CBT di Jawa Barat juga masih minim dilakukan pada 13 tahun ke belakang. Dari 10 penelitian terdahulu yang dianalisis pada penelitian ini (Tabel 2), perkembangan riset terkait pengembangan CBT di Jawa Barat baru mulai bermunculan pada tahun 2018 (Nurvantina et al., 2018; Andriani et al., 2018; Chamidah, et al 2018; Muhammad, 2018; dan Soepom et al, 2018). Artinya, riset terkait pengembangan CBT di Jawa Barat juga berpotensi sebagai topik yang perlu diangkat demi keberlanjutan, kebermanfaatan, dan kebaruan dalam ilmu pengetahuan pariwisata baik secara akademis dan juga secara praktis untuk pengambil keputusan.

\section{Simpulan}

Provinsi Jawa Barat memiliki potensi yang sangat besar untuk pengembangan CBT. Namun, dari keseluruhan pembahasan pengembangan CBT yang terdapat di Provinsi Jawa Barat dirasa masih kurang dalam implementasinya. Dari penelitan-penelitian terdahulu yang telah dilakukan, dapat terlihat sebuah tren yang berkembang bahwa peran masyarakat sebagai aktor utama menjadi isu strategis yang banyak dibahas. Namun demikian, penelitian dengan metode kuantitatif masih belum banyak dilakukan. Selain itu, isu sinergitas antar sektor dalam pengembangan pariwisata juga perlu ditingakatkan untuk memberikan dampak yang optimal bagi masyarakat. Perwujudan secara nyata pengembangan CBT di Provinsi Jawa Barat, menitikberatkan kepada peran stakeholder atau pemangku kepentingan yang masih minim komunikasi dan kolaborasi. Pada dasarnya, setiap sektor yang berjalan sendiri-sendiri di Provinsi Jawa Barat dapat membuat masyarakat sebagai pelaku yang menjalankan kegiatan pariwisata terkendala. Maka dari itu penelitian tentang peran dan sinergitas antar sektoral dalam pengembangan pariwisata bebasis masyarakat menjadi masukan bagi penelitian selanjutnya. Penggunaan metode dari pendekatan penelitian kuantitatif ataupun campuran untuk penelitian CBT di Jawa Barat ke depan, dapat dilakukan bagi peneliti selanjutnya untuk memperkaya khasanah keilmuan terkait CBT secara luas dan mendukung pembangunan CBT di Provinsi Jawa Barat secara khusus, melalui kajian yang lebih komprehensif.

Jurnal Socius: Journal of Sociology Research and Education Vol. 8, No. 1, Th. 2021 


\section{Rujukan}

Andriani, R., Kusumo, B., Charina, A., Deliana, Y., Gema, D. A. N., \& Mukti, W. (2018). Potensi Pengembangan Agrowisata Berbasis Komunitas Kabupaten Bandung Barat Potency Of Community-Based Agrotourism Development In Cibodas Villages Of Lembang Subdistrict Bandung Barat RegencY. Jurnal Ilmu Pertanian Dan Peternakan.

Chamidah, N., Imawan, K., \& Mudhofar, D. (2018). The Concept of Developing Local Wisdombased Tourism Villages in Cirebon Regency, West Java, Indonesia: Integrated Marketing Communication Perspective. https://doi.org/10.2991/icosop-17.2018.49

Danandjaja, J. (2014). Metode Penelitian Kepustakaan. Antropologi Indonesia. https://doi.org/10.7454/ai.v0i52.3318

Darsiharjo. (2016). Pengembangan Geopark Ciletuh Berbasis Partisipasi Masyarakat Sebagai Kawasan Geowisata Di Kabupaten Sukabumi. Jurnal Manajemen Resort Dan Leisure. https://doi.org/10.17509/jurel.v13i1.2036

Febriandhika, I., \& Kurniawan, T. (2020). Pengembangan Pariwisata Melalui Pemberdayaan Masyarakat Dilihat Dari Perspektif Implementasi Kebijakan. Jurnal Pariwisata Pesona. https://doi.org/10.26905/jpp.v5i1.2793

Ferdiansyah, H., Suganda, D., Novianti, E., \& Khadijah, U. L. (2020). Pengelolaan Mitigasi Krisis Pariwisata Akibat Pandemi Covid-19 Dalam Menghadapi Fase New Normal (Studi Kasus Di Desa Wisata Nglanggeran Yogyakarta). Open Journal Systems.

Fitriani, E., Selinaswati, S., \& Mardhiah, D. (2018). Partisipasi Masyarakat Dalam Pembangunan Ekowisata Sungai Pinang. Jurnal Socius: Journal of Sociology Research and Education. https://doi.org/10.24036/scs.v4i2.17

Hendrawan, H. (2016). Pada Kawasan Wisata Kamojang Kabupaten Bandung Evaluation Of Plan For Roadside Service Station Provision In Kamojang Tourism Region Bandung Regency. $13-20$.

Husni, A., \& Safaat, S. (2019). Pengembangan Desa Wisata Berbasis Partisipasi Masyarakat Lokal Di Desa Teluk Bakau, Kecamatan Gunung Kijang, Kabupaten Bintan. Jurnal Socius: Journal of Sociology Research and Education. https://doi.org/10.24036/scs.v6i1.135

Kartika, T., Afriza, L., \& Fajri, K. (2019). Pemberdayaan Masyarakat Di Desa Wisata Cibuntu Kabupaten Kuningan Provinsi Jawa Barat. Journal of Indonesian Tourism, Hospitality and Recreation. https://doi.org/10.17509/jithor.v2i1.16427

Kline, C. (2017). Applying the community capitals framework to the craft heritage trails of western North Carolina. Journal of Heritage Tourism, 12(5), 489-508. https://doi.org/10.1080/1743873X.2016.1226315

Koster, Rudolph W., et al. "European Resuscitation Council Guidelines for Resuscitation 2010 Section 2. Adult basic life support and use of automated external defibrillators." Resuscitation 81.10 (2010): 1277-1292.

Melfianora. (2017). Penulisan Karya Tulis Ilmiah Dengan Studi Literatur. Studi Litelatur, 1-3.

Muftiadi, A. (2017). Pengembangan Desa Wisata Dan Potensinya Di Kabupaten Pangandaran. AdBispreneur, 2(2), 117-124. https://doi.org/10.24198/adbispreneur.v2i2.13163

Muhammad. (2016). Implementation of Sustainable Tourism Destination Development Achievements. Hospitality and Tourism Industry, 3, 121-125.

Muhammad, F. (2018). Pesona Kearifan Lokal Sebagai Wahana Peningkatan Produktifitas Ekonomi Masyarakat. Jurnal Pemberdayaan Masyarakat: Media Pemikiran Dan Dakwah Pembangunan. https://doi.org/10.14421/jpm.2017.012-05

Nair, V., Thevi Munikrishnan, U., Devi Rajaratnam, S., \& King, N. (2014). Redefining Rural Tourism in Malaysia: A Conceptual Perspective Redefining Rural Tourism in Malaysia: A Conceptual Perspective. Asia Pacific Journal of Tourism Research. 
Nurvantina, E., Rahmafitria, F., \& Marhanah, S. (2018). Analisis Persepsi Pengelola Dan Masyarakat Mengenai Program Community Based Tourism Di Kampung Wisata Kreatif Eco Bambu Cipaku. Journal of Indonesian Tourism, Hospitality and Recreation. https://doi.org/10.17509/jithor.v1i1.13285

Oktini, D. (2007). Peran Perguruan Tinggi, Pemerintah dan Investor dalam Membangun Wisata Pedesaan Di Jawa Barat Sebagai Upaya Mengurangi Kemiskinan. MIMBAR, Jurnal Sosial Dan Pembangunan.

Pitanatri, P. D. S. (2020). Wisatawan Flashpacker: Sebuah Pendekatan Epistemologis. Jurnal Master Pariwisata (JUMPA). https://doi.org/10.24843/jumpa.2020.v07.i01.p04

Rahayu, Sugi, Utami Dewi, and Kurnia Nur Fitriana. "Pengembangan Community Based Tourism sebagai Strategi Pemberdayaan ekonomi Masyarakat di Kabupaten Kulon Progo, Daerah Istimewa Yogyakarta." Jurnal Penelitian Humaniora UNY 21.1 (2016): 124561

Rahmafitria, S., \& Rahmafitria, F. (2018). Analisis Persepsi Pengelola Dan Masyarakat Dalam Pengembangan Program Pelibatan Masyarakat Di Wana Wisata Kawah Putih. Journal of Indonesian Tourism, Hospitality and Recreation. https://doi.org/10.17509/jithor.v1i1. 13472

Rakhman, C. U. (2019). Pemberdayaan Masyarakat Sektor Pariwisata Budaya Di Kota Cimahi. Jurnal Pariwisata Pesona. https://doi.org/10.26905/jpp.v4i2.2705

Rencana Pembangunan Jangka Menengah Daerah (RJMD) Provinsi Jawa Barat Tahun 2008 2023

Rencana Induk Pembangunan Pariwisata Daerah (RIPPARDA) Provinsi Jawa Barat Tahun 2015 $-2025$

Rizkianto, N., Jurnal, T. T.-, \& 2018, U. (2018). Penerapan Konsep Community Based Tourism Dalam Pengelolaan Daya Tarik Wisata Berkelanjutan (Studi Pada Desa Wisata Bangun. Administrasi Bisnis Student Journal Universitas Brawijaya, 58(2), 20-26. http://administrasibisnis.studentjournal.ub.ac.id/index.php/jab/article/view/2402

Ruiz-Real, J. L., Uribe-Toril, J., de Pablo Valenciano, J., \& Gázquez-Abad, J. C. (2020). Rural tourism and development: Evolution in Scientific Literature and Trends. Journal of Hospitality and Tourism Research. https://doi.org/10.1177/1096348020926538

Soepom, S. R. F., Rahmafitria, F., \& Daluarti, M. H. . (2018). Pengembangan Program Pelibatan Masyarakat Di Wana Wisata Kawah Putih. Journal of Indonesian Tourism, Hospitality and Recreation, 1(1), 80-94.

Strydom, A. J., Mangope, D., \& Henama, U. S. (2019). Making community-based tourism sustainable: Evidence from the Free State province, South Africa. Geojournal of Tourism and Geosites, 24(1), 7-18. https://doi.org/10.30892/gtg.24101-338

Susyanti, D. W., \& Latianingsih, N. (2013). Potensi Desa melalui Pariwisata Pedesaan. Ekonomi Dan Bisnis.

Syafrini, D., Nurdin, M. F., Sugandi, Y. S., \& Miko, A. (2021). Transformation of a Coal Mining City into a Cultured Mining Heritage Tourism City in Sawahlunto, Indonesia: A Response to the Threat of Becoming a Ghost Town. Tourism Planning \& Development, 1-20.

Undang-Undang Republik Indonesia Nomor 10 Tahun 2009 Tentang Kepariwisataan 